DOI 10.18551/rjoas.2019-04.24

\title{
THE OWNERSHIP RIGHTS OF THE ASSETS EXCHANGEED IN BRIDEPRICE (BELIS) ACCOUNTING PRACTICES IN BELU
}

\author{
Manehat Beatrix Yunarti ${ }^{\star}$ \\ Master Program of Accounting, Faculty of Economics and Business, University of Brawijaya, \\ Indonesia
}

Irianto Gugus, Purwanti Lilik

Faculty of Economics and Business, University of Brawijaya, Indonesia

*E-mail: humas@ub.ac.id

\begin{abstract}
This study aims to understand to whom the ownership rights on assets exchanged as a bride price and repayment of marriage payments in Belu-Indonesia are given. This is important to be known by the parties who will issue assets in order not to harm one party considering the assets exchanged are classified as large. This study used a phenomenology method with seven informants who had direct subjective experience in customary marriages. The results of the study showed that from the two dozen costs with cultural values that formed the magnitude of the brideprice in Belu the bride did not has the rights to the assets of the brideprice. The parties that obtained ownership rights on the assets of the brideprice were the parents of the bride, biological uncle and family of the bride, religious leaders and local government. On the other hand, those who obtain ownership rights on the repayment of marriage payments given by women to men are the family of men. The man who will get married in the marriage also does not have the right on the assets from the repayment of marriage payment.
\end{abstract}

\section{KEY WORDS}

Ownership, bride price, repayment of marriage payments, Belu.

Transfers from male families to female families at the time of marriage occurred in twothirds of the population recorded at Murdock (1967) World Ethnographic Atlas of 1167 preindustrial societies. The Indigenous Tribe of Uma Duakun, Belu Regency, East Nusa Tenggara-Indonesia is also one of the tribes who participated in the brideprice transfer. In Belu Regency brideprice is called belis. Uniquely, on the brideprice payment in Belu District, which adheres to the patrilinear culture where men should pay brideprice (belis), the women apparently also provide assets at the time of marriage in return for marriage payments to men. Both parties exchange assets in the customary marriage. Brideprice given by men to women is usually varied in amount, for example, Rp. 60.000.000 from men to women, which is a form of 12 types of underlying costs and conversely the women give traditional/indigenous cloth and other forms of assets to men.

Considering the large amount exchanged in customary marriages, then it is important for men as the "giver of the brideprice" and the women as the "giver of repayment of marriage payments" to find out the target of their gift. The parties issuing the assets can know clearly to whom the brideprice is given, so that they can trust and issue assets in a certain amount for brideprice payments (belis). The clarity of the ownership rights of the brideprice (belis) and the repayment of marriage payments will minimize the bad view of the other party regarding "buying and selling transactions" which began to be widely discussed in the wedding tradition. This understanding will minimize the loss of the parties who exchange these assets because there is also concern regarding Dery's (2015) research in Ghana which found that infrequency often occurred in determining the brideprice where the brideprice was used as a means for female families to get out of their poverty zone. 
In recent years, this practice was critized, especially in Africa. A number of objections have been raised both in the media and in political discourse. Concerns about this arbitrariness make the practice of brideprice deemed contested as seen in examples in African newspapers that criticize this practice including Kelly (2006), IRIN News (2006), and Eryenyu (2014). Objection comes from the view that the transactional nature of the practice produces commodification of women and has adverse consequences. This research was conducted to trace the ownership rights of assets exchanged in the customary marriage of the Uma Duakun Indigenous Tribe in Belu District, either in the form of brideprice (belis) paid by men to women and in return for marriage payments given by women to men so all parties know clearly the ownership rights and purpose of the exchange of assets in the accounting practices of brideprice (belis) in customary marriages in Belu.

\section{METHODS OF RESEARCH}

Phenomenology focuses on human consciousness which is formed by a process by which humans feel, think about, and do what they believe according to Husserl (1970). The subjective experience of the informants about the establishment of the ownership rights of brideprice (belis) and the repayment of marriage payments form a quality of information that describes the situation that the informant actually feels. The informants in this study were seven people who had experienced and had direct experience regarding brideprice (belis) ownership rights and repayment of marriage payments. Ownership rights on the assets exchanged will be explored through the experience of the informants. The informant are the bride's father, the bride's mother, biological uncle of the bride, The groom's father, the mother of the groom, the groom and the bride. Data collection in this study was conducted in three ways namely direct observation, interviews and documentation studies. In this study the writers chose data analysis techniques that are in accordance with the phenomenological study approach as outlined by Sanders (1982). There are four stages in phenomenological analysis. The first stage is the researcher doing a description of the phenomenon based on the experience and awareness of the informant from the transcript of the interview results. The second stage researchers identified a theme that emerged based on the description in the first stage. The third stage researchers developed noema and noesis. Fourth stage researchers conducted a phenomenological data analysis by abstracting the essence of the correlation between noema and noesis. This abstraction process is called eidetic reduction.

\section{RESULTS AND DISCUSSION}

The ownership rights of the brideprice (belis) are given to the parents of the bride. The description of brideprice's (belis) ownership rights can be illustrated in the interview snippet with Mrs. $\mathrm{M}$ as the mother of the bride as follow:

'Yes, the money belongs to the parents. That's the parents' properties. The ownership rights on the belis belong to the parent. Belongs to father and mother".

The description of the interview (noema) above shows that the brideprice (belis) given by the male to female will be the property/ ownership rights of the bride's parents. The ownership rights of the bride price from the transfer made belong to parents in the Uma Duakun Indigenous Tribe, Belu Regency in accordance with what happened in Africa as stated in Anderson (2007) "Brideprice transfers, where the bride's parents receive the payment, are the norm in sub-Saharan Africa". This practice also corresponds to the distribution of brideprice's property/ ownership rights in marriage in Zimbabwe where the bride's mother at least gets the benefit of the brideprice payment for example in the form of a cow (Magena and Ndlovu, 2013).

The repeated mention of parents' names by Mrs. M implies that brideprice (belis) is the full right of the bride's father and mother. The Intentional analysis is that the assets given by men with various types of costs that make up the brideprice of women are delegated to the parents of women given the great services of parents who have cared until marry off their children. This price is a favor to the parents of the bride. 
Table 1 - The Amount of Brideprice and the Repayment of Marriage Payments at the Indigenous Tribe of Uma Duakun, Belu Regency

\begin{tabular}{|c|c|c|c|}
\hline No. & Value Name & $\begin{array}{l}\text { Amount of Payment from } \\
\text { male party to female }\end{array}$ & $\begin{array}{l}\text { The amount of payment from the female party to the } \\
\text { male }\end{array}$ \\
\hline 1. & $\begin{array}{l}\text { Parent Services (Breast milk) } \\
1 \text { piece of sofren (gold money) } \\
1 \text { cow that has } 1 \text { younger brother } 1 \\
\text { cow that has } 2 \text { younger brother }\end{array}$ & Rp 40.000 .000 & 1 piece of Indigenous cloth \\
\hline 2. & $\begin{array}{l}\text { Deku Dere (Knock the door): } \\
\text { Odamatan Lor (Front door) } \\
\text { Odamatan Rai (Back door) }\end{array}$ & $\begin{array}{l}\text { Rp } 1.000 .000 \\
\text { Rp } 500.000\end{array}$ & 1 piece of Indigenous cloth \\
\hline 3. & $\begin{array}{l}\text { Krima (virginity): } \\
\text { Abat ulun (Head tip) } \\
\text { Abat ain (Toe tip) }\end{array}$ & $\begin{array}{l}\text { Rp } 1.000 .000 \\
\operatorname{Rp} 500.000\end{array}$ & 1 piece of Indigenous cloth \\
\hline 4. & $\begin{array}{l}\text { Nae Biti Rai Kusin (a sign of } \\
\text { official bond) }\end{array}$ & Rp 1.000 .000 & 1 piece of Indigenous cloth \\
\hline 5. & $\begin{array}{l}\text { Toos molik uma maran (groom's } \\
\text { readiness) }\end{array}$ & Rp 250.000 & 1 piece of Indigenous cloth \\
\hline 6. & $\begin{array}{l}\text { Kous Fini (the entry of women in } \\
\text { the circle of life of the groom and } \\
\text { ready to use what has been } \\
\text { prepared by the groom) }\end{array}$ & Rp 250.000 & 1 piece of Indigenous cloth \\
\hline 7. & $\begin{array}{l}\text { Uma Rua (the union of the two } \\
\text { brides' families) }\end{array}$ & Rp 1.000 .000 & 1 piece of Indigenous cloth \\
\hline 8. & $\begin{array}{l}\text { Matebian (ancestral spirits of } \\
\text { ancestors). }\end{array}$ & $\begin{array}{l}\text { Rp } 250.000 \text { plus } 1 \text { pieces of } \\
\text { kbelak (can be in the form } \\
\text { of sofren / gold or silver } \\
\text { money) worth Rp } 6.000 .000\end{array}$ & 1 piece of Indigenous cloth \\
\hline 9. & $\begin{array}{l}\text { Aman no nan (thanks to uncles } \\
\text { and all families who have taken } \\
\text { the time to attend the event and } \\
\text { act as speakers in customary } \\
\text { marriages) }\end{array}$ & Rp 7.000 .000 & 1 piece of Indigenous cloth \\
\hline 10. & $\begin{array}{l}\text { Inan Kaliuk Aman Kaliuk this is } \\
\text { (notification to the village } \\
\text { government): } \\
\text { Village Head } \\
\text { Hamlet Chief }\end{array}$ & $\begin{array}{l}\text { Rp } 500.000 \\
\operatorname{Rp} 250.000\end{array}$ & 1 piece of Indigenous cloth \\
\hline 11. & $\begin{array}{l}\text { Chairman of the Environment } \\
\text { (Religious Leader) }\end{array}$ & Rp 250.000 & 1 piece of Indigenous cloth \\
\hline \multirow[t]{5}{*}{12.} & $\begin{array}{l}\text { Humur Malu Ibun Kaer malu Lian } \\
\text { (Trust and unity of the two } \\
\text { families) }\end{array}$ & Rp 250.000 & 1 piece of Indigenous cloth \\
\hline & & & $\begin{array}{l}\text { Koba (a place to store sirih-pinang): Per Koba (a } \\
\text { place to store sirih-pinang) Rp } 30.000 \text {. The total is } \\
\text { adjusted by the number of dulang (nampan) of the } \\
\text { groom's delivery during traditional/customary nights }\end{array}$ \\
\hline & & & $\begin{array}{l}\text { Tenasak (place to store food): Per Tenasak Rp } \\
25.000 \text {. Total tenasak needed depends on the } \\
\text { number of people who attended the traditional/ } \\
\text { customary event }\end{array}$ \\
\hline & & & $\begin{array}{l}\text { The cost of eating and drinking to entertain male } \\
\text { families (rice, vegetables, side dishes, sirih pinang, } \\
\text { cakes, etc.): This fee is adjusted to the number of } \\
\text { people present }\end{array}$ \\
\hline & $\begin{array}{l}\text { Total Value of Brideprice (Belis) \& } \\
\text { Repayment of Marriage Payments }\end{array}$ & Rp 60.000 .000 & $\begin{array}{l}12 \text { pieces of Indigenous cloth ( } 12 \text { pieces of } \\
\text { Indigenous fabric } \times \text { Rp. } 500,000 / \text { cloth = Rp. } \\
6.000 .000 \text { ). } \\
\text { Costs incurred for purchasing koba (a place to store } \\
\text { sirih-pinang), tenasak (place to store food) and food } \\
\text { and drinks according to the number of people } \\
\text { present and the menu that want to be served. }\end{array}$ \\
\hline
\end{tabular}

Source: Research results.

This gift will continue to be carried out as an implication. This understanding also occurs in the understanding of the nai' money in the Bugis tribe, Indonesia as a form of male family appreciation for the family of women for educating their daughters well (Rahayu and Yudi, 2015). The eidetic reduction that researchers can conclude is the manifestation of parental services to the bride as their child from childhood to adulthood making the parent 
possess the ownership rights of the brideprice. The meaning of appreciation and respect for parents is implied in the provision of these assets.

The views on property/ ownership rights above are complemented by the statement of Mr. I as the bride's father stating that the biological uncle of the bride also has the right to brideprice paid by men and women as the main actor in the marriage does not have the right on the assets that paid by the man in the marriage. Furthermore, Mr. I based on his understanding also added a statement about the rights of brideprice (belis) as follows:

"That, usually to the uncle. So whoever sits at that time, so the woman has uncles who sit talking about customs, sit and talk about belis, ha that is usually given. Then there was a little appreciation given to the parents of women and their brothers. Ha. The money will be shared later. Not for the woman's party. Ha. Sort of. This means that it is from the policy".

Noema of Mr. I illustrates that in the assets paid as brideprice by men to women there is a "part of assets" intended for biological uncles of the bride. Uncle (uncle) of the female bride is entitled to some of these assets because he has authority in the customary rules of the Indigenous Tribe of Uma Duakun Belu Regency as a figure who sets and talks with male families when customary sitting by sharing the negotiation process. This understanding of Mr. I was obtained when he was the father of the bride. Mr. I, based on his experience, appreciated the presence of biological uncles of the bride for his authority in accordance with the customary practices that occurred in the Indigenous Tribe of Uma Duakun Belu. This is an intentional analysis why the noesis of Mr.I understands that the bride's uncle has the right to the brideprice. The implication in each marriage at the Indigenous Tribe of Uma Duakun Belu, biological uncle of the bride will get the rights to some of the assets of the brideprice.

The conclusion that can be the writer abstraction from the phenomenology study on Mr. I (eidetic reduction) is that Mr. I follows the prevailing customs traditions. Compliance with the customary rules that make Mr. I always run the distribution of assets to the biological uncle of the bride as a form of appreciation to him for his great authority as the leader of settlers and indigenous speakers. Distributing the brideprice to the biological uncle of the bride's and making him possess his ownership rights is different from the practice in Italy and France, namely the bride is the party that gets the ownership rights to the brideprice as stated by Anderson (2007) "by the time the law codes were issued, the Visigoths (who ruled southwestern France and the Iberian peninsula) seem to have totally incorporated their ancient brideprice into the award grooms made to their brides. Similarly, the Lombards' (who conquered northern Italy) code of law made explicit a required dower to be given directly to brides, as did Frankish customs inthe Carolingian period (eighth to ninth century). This pattern is also reflected inthe traditional Chinese practice of transferring a brideprice directly to the bride'sparents, who then return a portion of this as dowry to their daughter. This amountis kept by the daughter as personal property throughout the marriage".

Mr. S based on his experience as the groom's father regarding the ownership rights of brideprice (belis) stated that the distribution of assets to the biological uncle was the authority of the bride's parents. The bride's parents have the authority to divide.

"They want to share or not it's up to the parents of the lady. If necessary, the uncle can get a cow, only now adjusted the parents will give to the uncle how much the uncle will receive. Whatever this parent has the right. Uncle, the one that talking about, so it's impossible, definitely want to get a little money".

The description (noema) above states that the property/ownership rights of brideprice (belis) is owned by the female parent in this case the biological father and mother of the bride and does not belong to the married bride. The biological parents of the bride have the full right to own and share brideprice (belis). When the researcher asked more about the uncle's rights to the brideprice, Mr. S added (noesis) that if in the past the brideprice (belis) belonged to the biological uncle of the bride fully, today it is no longer valid. Uncle of the bride will only get the money in accordance with the policies from the parents of the bride. Not only the uncle of the bride but all close family members sit on traditional/customary mats and also talk about setting the brideprice (belis) must be given a part. The biological uncle gets a part because he is a figure who in the customary rules has the highest authority to determine and discuss the value of brideprice (belis) of the bride. The property/ownership rights described 
by the informants as a reality in the Indigenous Tribe Uma Duakun Belu Regency has differences with the practice of Burgandi people according to Hughes (1985) research which states that by the fifth century, the Burgundians (who settled in Gaul) awarded one-third of their brideprice to their wives and two-thirds to their wives' kinsmen.

Complementing the statements of the informants above Mr. M as the uncle of the bride spelling out (noema) in more detail about the costs of brideprice (belis) which are the property/ ownership rights of the uncle based on his understanding.

"The money of Aman no nan. He thanked. Em, used to be like this. In the past, such as 7 million, not given like this. The kind I mentioned earlier, silver money. For example the leader, 10 silver, given separately. Uh, the vice how much he want? Want 7? There are levels. The other can be 5. Can be 4 silver, small children can 1-1 silver or 2 people gather 1 silver that is so".

Based on the understanding (noema), Mr. M above, the researcher can understand that the part of the brideprice which is specifically the property/ownership rights of the bride's uncle is the cost of aman no nan. Intentional Analysis is as the meaning of the costs of aman no nan which means the costs of thanking uncles and all families who have taken the time to attend the event and act as speakers in traditional/customary marriages namely respect for the families present are also prioritized in brideprice (belis) payments. Every family that attend especially the biological uncle of the woman who has the authority to sit on the custom mat and talk about brideprice (belis). As a form of appreciation to all those present at the customary wedding ceremony, all will get money from the payment of brideprice (belis). Everyone is given money according to his position in the family. For example, the leader of the tribe will get more money than the vice leader of the tribe. Even though the numbers are not the same, all the families present get money. Thus, the ownership rights on the cost of aman no nan is right if given to the uncle of the bride. From the total Rp. 7,000,000 which is part of the cost of aman no nan , the bride's parents have the authority to share in any amount and to each uncle and family who sit on custom mats. The statement of the informants again made the researchers conclude that the bride did not have the rights to the brideprice in her marriage. Not obtaining this ownership rights is in accordance with what stated by Anderson (2004) that In contrast to bridal bequests, women have no ownership rights over these more modern "groom-price" transfers.

The ownership rights on the repayment of marriage payments given by the female family to the male party explained based on the following understanding of Mr. I:

"Ha. Cloth. That later woman will return the custom, and then she will give. It already has rules too. Later she wants to give to whom to the brother of the female or repay to the mother. Or who will be present the point represents their moment. Ha, what are they usually. $O$, the time of the event that the item exchanged for the ring, the customary night, ha, who will accompany the lady later, maybe she has a brother, she has parents, especially she has that one uncle, ha it's usually those who get cloth. Ha, so that later they must get it.

Noema of Mr. I pointed out that ownership rights to cloth given to men by women in return for marriage payments will be given to uncles, brothers, mothers of the groom until the family of men who at the time of customary marriage accompanies the bride as a close family of the groom. If there is a form of reply in the form of money given by a female family to a male party, then the money will be distributed to the companion. On the other hand if the amount of money given in small amounts and is felt to be insufficient to be distributed to all male families who are assigned as a companion, then the money will be used to eat together by the entire male family.

In addition to replies in the form of indigenous cloth, repayment of marriage payments are also in the form of koba (a place to store sirih-pinang), tenasak (place to store food), and food and beverage costs. Tenasak (place to store food) indeed it was counted as a repayment of marriage payments but did not belong to men but still belonged to the family of women because it was only used as a food container for men during traditional/customary nights and not taken home by men. This can be seen from Mr. M's following interview:

"People eat, just a little must be in tenasak".

Mrs. $\mathrm{M}$ as the mother of the bride answered Mr. M's question as follows: 
"Tenasak Rp 25.000. Koba like that 30 thousand.. Eat it should be put in tenasak, not in plastic. If in the customary night put in tenasak this kind of stuff. Find tenasak Makerek, not the ordinary. Otherwise we don't want to".

The opinions conveyed by the informants based on the experience and awareness they carried out and experienced showed that tenasak (a place to store food) was owned by men in the sense of being a place to eat but not taken home by men. Tenasak (a place to store food) is owned by men and their families as a form of appreciation from women customarily namely giving food in tenasak the high value eating places in the eyes of the Indigenous Tribe of Uma Duakun in Belu Regency. Getting an appreciation by eating at Tenasak (a place to store food) rather than a plastic container made the men get an appreciation. The implication in traditional/customary marriage is that guests are not served food using dishes but are served food using tenasak (a place to store food) and serve sirih pinang using koba (a place to store sirih-pinang).

Can be concluded (eidetic reduction) by the writer that the ownership rights obtained by men and their families by eating using tenasak (a place to store food) is a sense of appreciated and honored which is certainly greater than any amount of money. The sense of being appreciated, accepted and honored also becomes the property/ownership rights of men and their families when served sirih-pinang in koba. Koba is a place to store sirih-pinang in the Indigenous Tribe of Uma Duakun, Belu Regency. Same as tenasak (a place to store food), koba is a high-value object that is considered to be a symbol of appreciation, acceptance and honor to anyone who is welcomed and served with sirih-pinang in koba when visiting. Koba (a place to store sirih-pinang) provided to welcome male families is the best quality koba (a place to store sirih-pinang), not just any koba (a place to store sirihpinang). This good selection of koba (a place to store sirih-pinang) again implies the meaning of appreciation in the koba (the place to store sirih-pinang). Men in the end did not have tenasak (a place to store food) and koba (a place to store sirih-pinang) in physical form but the value of the appreciation with the two containers made the men gain appreciation, respect and acceptance.

Payment of brideprice (belis) and repayment of marriage payments is a must in customary marriage. In addition to money, animals and other tangible objects that are exchanged in the tradition of customary marriage, there are also immaterial assets exchanged in traditional/customary marriages so that it becomes the property/ownership rights of both parties. Immaterial wealth which certainly cannot be measured by the value of money is something that is reflected in words and actions, feelings experienced by both parties as a result of the payment of brideprice (belis) and repayment of marriage payments. Immaterial property/ownership rights exist as a positive consequence obtained by both parties if they are able to pay brideprice (belis) and repayment of marriage payment, namely the good name and social status that retained its kindness. Marriage will be held well through the agreement of the two big families. This can be seen from the interview snippet (noema) of Brother Arnol as the groom following:

"The first is certainly feels proud means that this is a custom that must be fulfilled its meaning as a man proud to be able to pay. This means that this can also be a good name too. For belis, it has become the culture of the Timor that must be completed. Whoever, if in Timor, wants to marry someone's child, means that belis must be paid, it becomes an obligation. Now if we pay it becomes a pride, it means that our self-esteem can be valued by women".

Arnol's statement was supported by the opinion of Mr. I (noema) as the father of the bride as follow:

"Ha, that means that even if the belis is not, want to get married for free without the belis as a man, that is one self-esteem that he actually does not become he does not feel that he is a man. Because this belis is also part of a man's self-esteem that when he wants to get married he is capable, not only able to manage his family, but also the customary tradition that he has also long inherited from. Whether a little but at least it must be made. That's because it already concerns self-esteem. Male self-esteem is measured through that too. So basically this man is a prestige, so how can he if he doesn't pay for it and how is he 
to other men, then for a moment if there is a slight problem, surely it will be a shame for him, already married for free for my daughter, don't keep my daughter. If there is a man who wants a free marriage, this type of unemployed man so he wants free. What is clear is a time like that male family is ashamed, it must be".

Furthermore, Mr. S added the feeling (noema) that he felt from experience while paying brideprice (belis):

"Happy. Father and mother are happy because what is fully responsible has been finished so the father and mother are happy. Feel sad for what? Means that I am responsible".

This was also supported by the experience of Sister Years as the woman who paid the repayment of marriage payments as follows:

"First there is pride. Why is there pride? Because from there a man showed himself that he was ready and able to be married after that felt the second proud because in front of the woman's own family she felt that the man she chose was able to fulfill the obligations of a man before going on to the next stage. The point is there is a sense of pride, happy, proud and happy".

The understanding of the informants above shows that self-esteem, good name, pleasure and pride become the property/ownership rights of the groom Self-esteem illustrates how far the man considers himself to be capable, meaningful, valuable and competent. A man will get self-esteem as his property/ownership rights. The man feels he finds himself as a strong figure that capable of being responsible for brideprice's payment (belis). Men will feel gain pride and pleasure when he is able to pay the "value" of the woman he will marry. The good name of the man becomes elevated because of his ability and capability to pay the bride price (belis) that has been determined. Men are able to maintain the prestige inherent in him where he is able to demonstrate ability through payment of brideprice (belis). On the other hand, men feel able to give appreciation to the women and their families thus they are figures who cannot be underestimated or taken for granted by other parties. Immaterial property/ownership rights in the form of this appreciation are also traditionally felt in brideprice payments in Zimbabwe where appreciation and commitment are the main keys in brideprice payments (Mangena and Ndlovu, 2013). The payment process that is closely related to maintaining one's personal dignity is also in accordance with the values of the wisdom of South Sulawesi Culture stated by Poelinggomang (2014).

Men feel that paying brideprice (belis) is an obligation that has become a culture in marriage and thus must be carried out in traditional/customary marriage. Furthermore, immaterial property/ownership rights for parents namely will feel happy if they are able to pay brideprice (belis) because they feel their responsibility has been completed. Feeling has reached the stage where the child is able to build a new family. Parents have been able to maintain, guide, raise and educate their children until they reach the marriage stage. Parental happiness as a manifestation of responsibility that has been carried out so far. The bride as the person to be married feels a sense of pride and pleasure. Both of these are property/ownership rights of woman because they feel they have chosen the right man who is able to be responsible as a man for paying brideprice (belis) obligations according to the prevailing customary tradition. The woman also proud because she had gotten a man who actually showed his readiness to foster a household and who was declared ready to become the head of the family not only in the eyes of the bride personally but was able to prove it to the whole family.

In addition to the description above the other immaterial property/ownership rights owned by the parents is such as the statement of Mrs. T as the groom's mother the following:

"Ha, that is mutual respect for one another. Women respect us men. We men respect women. Happy too. Yes, happy. Means that is our customary tradition must be run. Impossible o nawan sae ema, happy, glad. Mother is happy because gets a son-in-law, can't say it's sad that's for the happiness of our children".

Respect is emphasized as property/ownership rights acquired by both parties in this customary marriage process. By issuing large amounts of money for brideprice (belis) in marriage parents do not feel angry but feel great happiness as a form of making children 
happy and getting new family members. Happy feelings arise because brideprice (belis) is not used as a burden that interferes with the course of marriage but is seen positive as the good culture that must be carried out for legally as husband and wife.

On the other hand there are consequences that must be borne by men if they are unable to pay brideprice (belis). The same consequences will also be borne by the woman if she is unable to give the repayment of the marriage payment. The consequences obtained were in the form of social sanctions which would be received by the two big families from the community. Both families will be the talk of the community. Shame will be borne for a lifetime by both families. Their inability to pay brideprice (belis) will be discussed as a weakness. Another consequence that will also be obtained is the cancellation of marriage. The cancellation of marriage will disrupt the psychology of man and woman who will marry.

Furthermore, the negative consequences obtained if a man cannot afford brideprice (belis) will be borne by man and their families. The man will feel not being a man in front of other people, especially risking their good name with other man. Another consequence that is obtained in the form of feelings of inferiority, ostracized from the association of several parties, underestimated until undervalued by the female family and the people around will be felt as a result of the inability of a man to pay brideprice (belis). This can be seen in the interview snippet with Brother Arnol's as the groom as follows:

"The perceived impact is the first that we automatically feel inferior. The second was ostracized from a number of people, became people's speeches, and became the material for the neighbors to talk. The third is that we are less valued. Appreciated by the female family means that underestimated"

Similar negative consequences will also be felt by the woman if unable to give the repayment of marriage payments. This is evidenced by the description of Sister Years' interview as the bride following:

"If can not give indigenous cloth or can't entertain, of course, the feelings feel discouraged. Discouraged for what? Because it can't, the point is like, cannot accept the family of men who have come well. So if it is not fulfilled the female family also feels sad because cannot give feedback to the male family well. The point is, for example, if a female family cannot repay a male family by entertaining or giving traditional/indigenous cloth, it means that the female family is also not ready to continue the proposal, because if for instance is ready the family for both parties it means that the female family has also ready to give obligations to a male family or banquet".

The description above shows that women will also feel a feeling of being discouraged if they are unable to give repayment of marriage payments. This is felt as a result of the inability to balance the good things that have been done by men and their families. Women will be sad and feel they are not ready to do the marriage if they have not been able to conduct the repayment of marriage payment. This also indicates that both parties must prepare themselves properly, not only imposing on the male side or vice versa imposing on the woman if want the marriage is to be carried out. The readiness of both parties also became the main key in marriage.

\section{CONCLUSION}

The ownership rights of the brideprice (belis) given by the men are owned by the bride's parents and there are certain costs given to the family in this case the bride's uncles, government figures and religious leaders. Property/ownership rights on the tangible assets given as brideprice namely in the form of money by men to women are the parents' rights to the bride. As for assets that are the property/ownership rights of the parents are the money of parents' fees/services (Breast Milk), Deku Dere (Knock the Door): Oda Matan Lor (Front door), Oda Matan Rae (Back door), Krima (virginity): Abat Ulun, Abat Ain, Nae Biti Rai Kusin(a sign of official bond), Toos Molik Uma Maran (groom's readiness), Kous Fini (the entry of women in the circle of life of the groom and ready to use what has been prepared by the groom), Uma Rua (the union of the two brides' families), Matebian (ancestral spirits of ancestors), and Humur Malu Ibun Kaer Malu Lian (trust and unity of the two families). Thus 
the total assets that became the ownership rights of the bride's parents from the value of the brideprice (belis) paid equal to Rp. 51.250.000. The property/ownership rights on the other assets which categorized as the cost of Aman No Nan (thanks to uncles and all families who have taken the time to attend the event and act as speakers in traditional/customary marriages) is the property/ ownership rights of biological uncle of the bride. Assets in the form of money that become the property/ownership rights of the bride's uncle equal to Rp 7.000.000. The money of Inan Kliuk Aman Kliuk (the cost of permits and notifications to the village government) became the property/ownership rights of the government apparatus

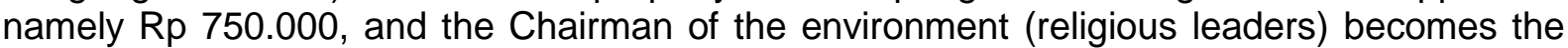
property/ownership rights of the chairman of the environment (religious leader) with an amount of $\mathrm{Rp} 250.000$.

Furthermore, for repayment of the marriage payment paid by the female to the male, the ownership rights to the assets in the form of traditional/indigenous cloth given as the repayment of the marriage payment given by the male are the property of the parents of the groom and the male family who accompany bride on customary night. The number of indigenous cloth obtained are as many as 12 pieces of indigenous cloth with good quality. Other property/ownership rights obtained by men and their families by eating using tenasak (a place to store food) is a sense of respected and appreciated which is certainly greater than any amount of money even though physically koba (a place to store sirih-pinang), tenasak (a place to store food) not owned by men and their families. Sense of being appreciated, accepted and valued that became the property/ownership rights of men and their families when served sirih-pinang in koba as well as food with good quality in tenasak. As for the number of koba (a place to store sirih-pinang), tenasak (a place to store food), as well as the cost of banquet and drinking for a male family according to the number of families that present and enjoying the food prepared by a female family.

In addition to tangible assets, immaterial wealth is also exchanged by both families involved in customary marriages. The property/ownership rights on the immaterial wealth obtained by the two families in the form of the sense of respected, sense of honored, selfesteem, good name, pride, pleasure, are the rights that belong to all those involved in the customary marriage of the Indigenous Tribe of Uma Duakun in Belu Regency. The inability of both parties to fulfill brideprice (belis) payments and repayment of marriage payments will also have negative consequences in the form of shame, feeling excluded, not respected, being the material of people's speech also become the property/ownership rights of both families involved. For further research, researchers suggest conducting research that focuses on the source of capital used for payment of marriage by men and repayment of marriage payments by women.

\section{REFERENCES}

1. Anderson, Siwan. 2007, "The Economics of Dowry and Brideprice". Journal of Economic Perspectives, Vol. 21, No. 4, hal. 151-174.

2. Anderson, Siwan. 2004. "Dowry and Property Rights." BREAD Working Paper 80.

3. Dery, I. 2015. "Bride price and domestic violence: Empirical perspectives from Nandom Districtin the north westernregion of Ghana". International Journal of Development Sustainability, Vol.4 No. 3, hal 258-271

4. Eryenyu, J. (2014). 'Payment of Bride Price Turns Women into Commodities'. Daily Monitor. Available at: www.monitor.co.ug/OpEd/Letters/Payment-of-bride-price-turnswomen-into-commodities/806314-2447104-n41iwj/index.html (accessed 02 Maret 2019).

5. Hughes, Diane O. 1985. "From Brideprice to Dowry in Mediterranean Europe." In TheMarriage Bargain: Women and Dowries in EuropeanHistory, ed. Marion A. Kaplan, 13-58. New York: Havorth Press.

6. Husserl, E. 1970. The Crisisof European Sciences and Transendental Phenomenology. University Press. Northwestern. 
7. IRIN News (2006). 'Study Links Payment of Bride Price to Abuse of Women'. Available at: $\quad$ www.irinnews.org/report/59032/tanzania-study-links-payment-bride-price-abusewomen (accessed 02 Maret 2019).

8. Kelly, A. (2006). 'Why Girls are economically challenged'. The Guardian. Available at: www.theguardian.com/katine/2009/aug/17/money-women (accessed 02 Maret 2019).

9. Mangena, T. Ndlovu, S. 2013. Implications and Complications of Bride Price Payment Among The Shona And Ndebele Of Zimbabwe. International Journal of Asian Social Science, 2013, 3(2):472-481.

10. Murdock, George P. 1967. Ethnographic Atlas. Pittsburgh: University of Pittsburgh.

11. Poelinggomang, E. L. 2014. Nilai-nilai and Kearifan Budaya Sulawesi Selatan. Paper presented at the Pertemuan MAMI Nasional 2 (Teman 2), 20 Juni, Makassar

12. Rahayu and Yudi. 2015. "Uang Na'i: Antara Cinta and Gengsi". Jurnal Akuntansi Multiparadigma, Vol. 6, No. 2, hal.224-236.

13. Sanders, P. (1982). Phenomenology: A New Way of Viewing Organizational Research. Academy of Management Review. 7 (3), 353-360. 